\title{
Pengaruh Jenis dan Cara Aplikasi Pupuk Kandang Terhadap Pertumbuhan dan Hasil Tanaman Tomat (Lycopersicum esculentum, Mill)
}

Anastasia Usfunan ${ }^{\mathrm{a}}$

${ }^{a}$ Fakultas Pertanian, Universitas Timor, Kefamenanu, TTU - NTT, 85613, Indonesia

\section{Article Info}

Article history:

Received 10 September 2015

Received in revised form 18 Januari 2016

Accepted 16 Februari 2016

\section{Keywords:}

Jenis Pupuk Kandang

Cara Aplikasi

Tomat

\begin{abstract}
Abstrak
Penelitian ini bertujuan untuk mengetahui pengaruh jenis dan cara aplikasi pupuk kandang terhadap pertumbuhan dan hasil tanaman tomat serta mengetahui cara aplikasi yang tepat dari setiap jenis pupuk kandang. Rancangan yang digunakan dalam penelitian ini adalah Rancangan Petak Terbagi (Split Plot Design) pola faktorial yang diulang sebanyak tiga kali. Faktor petak utama adalah jenis pupuk yang terdiri dari tiga aras yaitu pupuk kandang ayam, pupuk kandang sapi dan pupuk kandang kambing. Faktor anak petak adalah cara aplikas pupuk yang terdiri dari tiga aras yaitu tebar, pop up dan fertigasi. Hasil penelitian menunjukkan interaksi antara jenis dan cara aplikasi pupuk kandang hanya berpengaruh nyata terhadap diameter batang 14 HST, jumlah buah per anak petak dan indeks panen. Jenis pupuk kandang nyata mempengaruhi suhu tanah setiap waktu pengamatan, berat volume tanah 14 HST, tinggi tanaman 14 HST dan 28 HST, berat per buah, jumlah buah per tanaman dan jumlah buah per anak petak, sedangkan cara aplikasi berpengaruh nyata terhadap kada lengas tanah 28 HST, tinggi tanaman 42 HST, diameter batang 14 HST dan 28 HST. Setiap jenis pupuk kandang mempunyai cara aplikasi yang berbeda untuk berfungsi dengan baik terhadap tanaman tomat, pupuk kandang ayam lebih baik jika diaplikasikan menggunakan cara pop up dengan hasil mencapai 74,543 t/ha, pupuk kandang sapi lebih baik jika diaplikasikan menggunakan cara tebar dengan hasil mencapai 74,468 t/ha sedangkan pupuk kandang kambing lebih baik jika diaplikasikan menggunakan cara fertigasi dengan hasil mencapai 71,714 t/ha. (02016 dipublikasikan oleh Savana Cendana.
\end{abstract}

\section{Pendahuluan}

Tomat (Lycopersicum esculentum, Mill) merupakan sayuran populer d Indonesia. Tomat sebagai komoditi hortikultura merupakan sumber vitamin dan mineral yang sangat bermanfaat bagi pemenuhan gizi dalam tubuh manusia, zat asam askorbat dan karoten, yang terkandung dalam tomat, merupakan sumber zat yang sangat penting dan dapat meningkatkan aktivitas tubuh. Kandungan vitaminnya dapat mencegah berbagai penyakit seperti sariawan, gusi berdarah dan rabun jauh (Tugiyono, 2001). Menurut Asniah (2012), permintaan pasar baik dalam maupun luar negeri terhadap buah tomat setiap tahunnya terus meningkat. Meningkatnya permintaan ini disebabkan oleh beberapa faktor diantaranya membaiknya tingkat pendapatan dan kesejahteraan masyarakat, semakin sadarnya masyarakat akan pemenuhan gizi yang baik dan semakin bertambahnya permintaan bahan baku untuk keperluan industri obat-obatan.

Produksi tomat di Kabupaten Timor Tengah Utara (TTU), dari 2007- 2010 berfluktuasi dan sempat meningkat tinggi pada tahun 2009 yang mencapai 259 ton tetapi menurun pada tahun 2010 yakni hanya 99 ton. Secara nasional produksi tomat pada tahun yang sama sebesar 891.616 ton pada luas panen 61.154 ha dengan produktivitasnya sebesar 14,58 t/ha (BPS, 2014). Produktivitas ini jauh lebih rendah dibandingkan dengan potensi produksi tomat varietas Lentana yang dapat mencapai 40-60 t/ha

Pertumbuhan tanaman tomat akan baik pada tanah yang mengandung banyak bahan organik, unsur hara, baik makro maupun mikro serta kandungan air tanah yang cukup dan seimbang. Pulau Timor umumnya dan Kabupaten Timor Tengah Utara (TTU) khususnya didominasi oleh tanah-tanah marginal yang mempunyai kesuburan rendah atau miskin unsur hara sehingga kurang mendukung pertumbuhan tanaman. Salah satu upaya yang dapat dilakukan untuk menanggulangi hal tersebut dengan penambahan unsur hara melalui pemupukan

Pemupukan merupakan syarat mutlak dalam membudidayakan suatu tanaman, pemupukan bertujuan untuk menggantikan unsur hara yang hilang karena proses pencucian dan pengangkutan bersama limbah pertanian (Santoso,1994). Kesadaran akan pentingnya pertanian berkelanjutan dan kesulitan untuk mendapatkan serta mahalnya harga pupuk anorganik pada kalangan petani mengarahkan untuk pemanfaatan limbah organik yang murah, tersedia dan ramah lingkungan yang bisa digunakan sebagai pupuk organik seperti kotoran-kotoran hewan. Menurut Novizan (2004), pupuk kandang adalah pupuk yang berasal dari kotoran-kotoran hewan yang bercampur dengan sisa makanan dan urin yang di dalamnya mengandung unsur hara $\mathrm{N}, \mathrm{P}$ dan $\mathrm{K}$ yang dapat digunakan untuk kesuburan tanah.

Kegiatan pemupukan tanaman harus mempertimbangkan faktor-faktor antara lain tanaman yang akan dipupuk, jenis pupuk yang digunakan, dosis pupuk, cara aplikasi pupuk dan waktu pemupukan. Pemberian pupuk yang benar akan memberikan hasil yang baik pula karena pupuk dapat terserap baik oleh tanaman, dengan demikian pemanfaatan unsur hara yang terkandung dalam pupuk dapat dimaksimalkan oleh tanaman dalam proses pertumbuhan tanaman itu sendiri. Kesalahan dalam cara pemberian pupuk akan mengurangi efesiensi dan efektifitas pupuk, sehingga akan timbul kerugian dari sisi waktu dan biaya serta manfaat pupuk yang kurang maksimal bagi tanaman.

Jenis pupuk kandang yang banyak tersedia di lingkungan masyarakat antara lain pupuk kandang ayam, pupuk kandang sapi dan pupuk kandang kambing, dimana ketiganya memiliki bentuk fisik dan kandungan yang berbeda. Selain jenis pupuk yang tepat, cara aplikasi pupuk yang efektif dan efesiensi akan meningkatkan keberhasilan pemupukan. Permasalahan yang melatarbelakangi penelitian ini adalah belum diketahui tentang pengaruh jenis dan cara aplikasi pupuk kandang terhadap pertumbuhan dan hasil tomat kelurahan manunain A di Kabupaten TTU.
Penelitian ini bertujuan untuk mengetahui pengaruh jenis dan cara aplikasi pupuk kandang terhadap pertumbuhan dan hasil tanaman tomat serta mengetahui cara aplikasi yang tepat dari setiap jenis pupuk kandang.

\section{Metode}

2.1 Waktu dan Tempat

Penelitian dilaksanakan pada bula Mei sampai bulan Agustus tahun 2015 di Kelurahan Manunain A, Kecamatan Insana, Kabupaten TTU.

\subsection{Rancangan Percobaan}

Rancangan yang digunakan dalam penelitian ini adalah Rancangan Petak Terbagi (Split Plot Design) pola faktorial $3 \times 3$ yang diulang sebanyak tiga kali. Faktor petak utama adalah jenis pupuk $(\mathrm{J})$ yang terdiri dari tiga aras yaitu pupuk kandang ayam $\left(\mathrm{j}_{1}\right)$, pupuk kandang sapi $\left(\mathrm{j}_{2}\right)$ dan pupuk kandang kambing $\left(\mathrm{j}_{3}\right)$. Faktor anak petak adalah cara aplikasi pupuk (C) yang terdiri dari tiga aras yaitu tebar $\left(c_{1}\right)$, pop up $\left(c_{2}\right)$ dan fertigasi $\left(c_{3}\right)$. Kombinasi perlakuannya adalah $\mathrm{j}_{1} \mathrm{c}_{1}, \mathrm{j}_{1} \mathrm{c}_{2}, \mathrm{j}_{1} \mathrm{c}_{3}, \mathrm{j}_{2} \mathrm{c}_{1}, \mathrm{j}_{2} \mathrm{c}_{2}, \mathrm{j}_{2} \mathrm{c}_{3}, \mathrm{j}_{3} \mathrm{c}_{1}, \mathrm{j}_{3} \mathrm{c}_{2}$ dan $\mathrm{j}_{3} \mathrm{c}_{3}$

\subsection{Pelaksanaan Penelitian}

a. Persiapan Benih

Benih yang digunakan dalam penelitian ini adalah benih tomat varietas Lentana. Sortasi dilakukan dengan cara merendam benih dalam air,benih yang baik adalah benih yang terendam dalam air. Benih dibeli dari toko sarana produksi pertanian sebanyak dua bungkus.

b. Persemaian

Benih disemaikan langsung dalam polybag yang terbuat dari daun pisang dengan ukuran $10 \mathrm{~cm} \times 10 \mathrm{~cm}$. Media tanam yang digunakan adalah campuran tanah (top soil) dan pasir dengan perbandingan 2:1. Media tanam kemudian dimasukan dalam polybag. Selanjutnya pada permukaan media tanam dibuat lubang sedalam $1 \mathrm{~cm}$, kemudian ditanam benih tomat satu butir untuk setiap polybag dan ditutup dengan media tanam. Penyiraman menggunakan hand sprayer dua kali sehari pada pagi dan sore hari. Setelah bibit berumur 30 hari, bibit siap dipindahkan ke lahan percobaan. Bibit yang disiapkan sebanyak 743 tanaman (kebutuhan 675 tanaman dan 78 bibit cadangan)

c. Pengolahan Tanah

Tanah terlebih dahulu dibersihkan dari gulma dan vegetasi lainnya untuk selanjutnya dilakukan pengolahan. Pengolahan tanah dilakukan dengan menggunakan cangkul, kemudian dilanjutkan dengan penggemburan tanah Lahan yang digunakan berukuran panjang $19,5 \mathrm{~m}$ dan lebar $9 \mathrm{~m}$ dengan luas $175,5 \mathrm{~m}^{2}$. Lahan dibagi dalam tiga blok dan pada masing-masing blok dibua tiga petak utama yang masing-masing terdiri dari tiga anak petak percobaan dengan ukuran panjang $2 \mathrm{~m}$, lebar $1,5 \mathrm{~m}$ dan tinggi $20 \mathrm{~cm}$ sehingga secara keseluruhan terdapat 27 anak petak. Jarak antara anak petak $0,5 \mathrm{~m}$, jarak antara petak utama dan jarak antara blok $1 \mathrm{~m}$. Pada setiap blok, petak utama, anak petak dan tanaman sampel diberikan label menggunakan tiang bambu dan seng. d. Aplikasi Pupuk dengan Cara Disebar

Jenis pupuk dan cara aplikasinya sesuai dengan perlakuan dengan menggunakan dosis $20 \mathrm{t} / \mathrm{ha}$ atau $6 \mathrm{~kg}$ per petak atau $240 \mathrm{~g}$ per tanaman. Pada tiga anak petak yang berlabel $j_{1} c_{1}$ diberikan pupuk kandang ayam dengan cara ditebar merata di permukaan kemudian dicampur dengan tanah, pada tiga anak petak yang berlabel $\mathrm{j}_{2} \mathrm{c}_{1}$ diberikan pupuk kandang sapi dan pada tiga anak petak yang berlabel $\mathrm{j}_{3} \mathrm{c}_{1}$ diberikan pupuk kandang kambing dengan cara aplikasi yang sama. Aplikasi pupuk dilakukan pada hari penanaman.

e. Aplikasi Pupuk dengan Cara Pop Up

Sebelum penanaman, dilakukan pembuatan lubang tanam pada anak petak dengan ukuran diameter $15 \mathrm{~cm}$ sedalam $15 \mathrm{~cm}$ menggunakan jarak tanam $40 \mathrm{x}$ $30 \mathrm{~cm}$. Selanjutnya setiap lubang tanam pada tiga anak petak yang berlabel $\mathrm{j}_{1} \mathrm{c}_{2}$ 
diberikan pupuk kandang ayam sebanyak $240 \mathrm{~g}$, setiap lubang tanam pada tiga anak petak yang berlabel $\mathrm{j}_{2} \mathrm{c}_{2}$ diberikan pupuk kandang sapi sebanyak $240 \mathrm{~g}$ dan setiap lubang tanam pada tiga anak petak yang berlabel $\mathrm{j}_{3} \mathrm{c}_{2}$ diberikan pupuk kandang kambing sebanyak $240 \mathrm{~g}$.

f. Aplikasi Pupuk dengan Cara Fertigo

Sebanyak $18 \mathrm{~kg}$ pupuk kandang ayam, $18 \mathrm{~kg}$ pupuk kandang sapi dan 18 kg pupuk kandang kambing masing-masing direndam dalam 36 liter air (perbandingan $0,5 \mathrm{~kg}$ pupuk per liter air). Selanjutnya cairan pupuk kemudian disiram secara merata di permukaan anak petak setelah penanaman. Pada tiga anak petak yang berlabel $\mathrm{j}_{1} \mathrm{c}_{3}$ disiram dengan cairan pupuk kandang ayam sebanyak 12 liter per petak, pada tiga anak petak yang berlabel $\mathrm{j}_{2} \mathrm{c}_{3}$ disiram dengan cairan pupuk kandang sapi sebanyak 12 liter per petak dan pada tiga anak petak yang berlabel $\mathrm{j}_{3} \mathrm{c}_{3}$ disiram dengan cairan pupuk kandang kambing sebanyak 12 liter per petak. Kebutuhan total pupuk dalam penelitian ini adalah $162 \mathrm{~kg}$ dengan perincian $54 \mathrm{~kg}$ pupuk kandang ayam, $54 \mathrm{~kg}$ pupuk kandang sapi dan $54 \mathrm{~kg}$ pupuk kandang kambing.

\section{g. Penanaman}

Penanaman dilakukan dengan cara mengambil bibit kemudian merobek atau melepas polybag, lalu masukkan tanaman beserta tanah yang terdapat di polybag ke dalam lubang tanam. Penanaman dilakukan pada saat sore hari. Jumlah tanaman dalam setiap anak petak adalah 25 tanaman dengan jumlah keseluruhan 675 tanaman

h. Pemeliharaan

Pemeliharaan meliputi penyiraman, penyulaman, penyiangan serta pengendalian hama dan penyakit tanaman. Penyiraman dilakukan menggunakan gembor pada pagi dan sore hari. Penyulaman dilakukan pada saat tanaman berumur 10 HST. Penyulaman dilakukan dengan cara mengganti bibit yang mati atau rusak dengan bibit cadangan yang telah disiapkan.sebayak 78 bibit cadangan,dan bibit yang diganti saat penelitian sebanyak 20 tanaman. Penyiangan terhadap gulma dilakukan dengan mencabutnya, namun dilakukan hati-hati sehingga akar tanaman tidak terganggu. Pengendalian HPT dilakukan apabila tanaman mengalami serangan hama dan penyakit. Selama peneitan hama yang menyerang tanaman adalah hama ulat buah,dan dikendalikan dengan cara memetik buah yang diserang hama buah tersebut.

i. Panen

Panen dilakukan setelah buah matang (masak) dengan ciri-ciri berwarna merah kekuning-kuningan dengan cara dipetik. Pemanenan dilakukan 3 kal dengan jarak waktu 1 minggu, panen yang ketiga dilakukan secara rampasan atau panen semua buah. Umur panen tomat varietas Lentana adalah 75- 102 hari.

\subsection{Parameter Pengamatan}

a. Suhu Tanah $\left({ }^{\circ} \mathrm{C}\right)$

Pengukuran suhu tanah dilakukan tiga kali selama penelitian yakni 14 HST, 28 HST dan 42 HST, menggunakan thermometer suhu tanah, dengan cara ditancapkan pada kedalaman tanah $5 \mathrm{~cm}$ selama 3 menit pada tiga titik untuk setiap anak petak lalu dicatat. Pengukuran dilakukan pada siang hari puku 12.00-14.00 WITA

b. Kadar Lengas Tanah $(\%)$

Sampel tanah di ambil dengan cara menggali sedalam $5 \mathrm{~cm}$ pada tiga titik untuk setiap anak petak. Sampel tanah yang sudah diambil berbentuk gumpalan $+2 \mathrm{~cm}$, disimpan dalam wadah plastik yang ditandai dengan label, kemudian ditimbang untuk mengetahui berat basah, selanjutnya tanah dioven selama 48 jam pada suhu $105{ }^{\circ} \mathrm{C}$, kemudian ditimbang untuk mengetahui berat kering. Pengukuran dilakukan sebanyak tiga kali selama pertumbuhan yakni 14 HST, 28 HST dan 42 HST. Kadar lengas tanah dihitung dengan rumus

$$
\begin{aligned}
& \mathrm{KL}=\frac{\mathrm{BB}-\mathrm{BK}}{\mathrm{BK}} \times 100 \% \\
\text { Keterangan } & : \\
\text { KL } & \text { : Kadar Lengas Tanah }(\%) \\
\text { BB } & : \text { Berat Basah }(\mathrm{g}) \\
\text { BK } & : \text { Berat Kering }(\mathrm{g})
\end{aligned}
$$

c. Berat Volume Tanah $\left(\mathrm{g} / \mathrm{cm}^{3}\right)$

Sampel tanah kering dari pengukuran kadar lengas tanah kemudian diikat dengan tali raffia sepanjang $10 \mathrm{~cm}$ dan dicelupkan ke dalam cairan lilin dalam wadah alumunium yang dipanaskan dengan lampu spritus. Gumpalan tanah yang telah dilipasi lilin dicelupkan ke dalam gelas ukur berisi air setinggi $40 \mathrm{ml}$. Kenaikan volume air dihitung sebagai volume tanah. Berat volume tanah dihitung dengan rumus:

$$
\mathrm{BV}=\frac{\mathrm{B}}{\mathrm{V}}
$$

Keterangan

$\begin{array}{ll}\text { BV } & \text { : Berat Volume Tanah }\left(\mathrm{g} / \mathrm{cm}^{3}\right) \\ \mathrm{B} & : \text { Berat Tanah Kering }(\mathrm{g}) \\ \mathrm{V} & : \text { Volume Tanah }\left(\mathrm{cm}^{3}\right)\end{array}$

d. Tinggi Tanaman $(\mathrm{cm})$

Tinggi tanaman diukur dari pangkal batang sampai ujung daun paling tinggi, pengukuran menggunakan pengaris centimeter. Pengukuran dilakukan pada lima tanaman sampel saat berumur 14 HST, 28 HST dan 42 HST.

\section{e. Diameter Batang $(\mathrm{cm})$}

Pengukuran diameter batang dilakukan dengan menggunakan jangka sorong dengan cara menjepit pada bagian batang $(1 \mathrm{~cm}$ di atas pangkal batang) dari lima tanaman sampel pada setiap anak petak. Pengukuran dilakukan pada saat tanaman berumur 14 HST, 28 HST dan 42 HST.

f. Luas Daun $\left(\mathrm{cm}^{3}\right)$

Pengukuran luas daun dilakukan pada saat tanaman berumur 42 HST. Pengukuran luas daun dilakukan menggunakan metode fotografi dengan cara mengambil semua daun pada tiga tanaman korban pada tiap petak, kemudian daun dipotret menggunakan kamera digital. Luas area daun kemudian dihitung menggunakan program ImageJ versi 1.41 o.

g. Diameter Buah $(\mathrm{cm})$

Pengukuran diameter buah dilakukan dengan menggunakan jangka sorong dengan cara menjepit pada bagian buah yang terbesar. Buah yang diukur adalah semua buah yang dipanen dari lima tanaman sampel pada setiap anak petak kemudian dirata-ratakan. Pengukuran dilakukan setiap kali panen kemudian dirata-ratakan untuk memperoleh ukuran diameter buah.

h. Berat Per Buah (g)

Berat per buah diukur dengan cara menimbang buah tomat menggunakan timbangan analitik. Buah yang ditimbang adalah semua buah yang dipanen dari setiap tanaman sampel pada semua anak petak kemudian dirata-ratakan dengan cara berat total dibagi dengan jumlah buah. Pengukuran dilakukan setiap kali panen kemudian dirata-ratakan untuk memperoleh ukuran berat per buah.

i. Jumlah Buah Per Tanaman

Buah yang dipanen dari lima tanaman sampel dihitung kemudian dirataratakan. Perhitungan dilakukan setiap kali panen kemudian dijumlahkan untuk mendapatkan jumlah buah tomat per tanaman.

j. Berat Buah Per Tanaman $(\mathrm{g})$

Berat buah per tanaman diukur dengan cara menimbang buah tomat menggunakan timbangan analitik. Buah yang ditimbang adalah semua buah yang dipanen dari lima tanaman sampel pada setiap anak petak kemudian dirata-ratakan dengan cara berat total dibagi dengan jumlah tanaman sampel. Pengukuran dilakukan setiap kali panen kemudian dijumlahkan untuk memperoleh ukuran berat buah per tanaman.

k. Jumlah Buah Per Anak Petak

Buah yang dipanen dari semua tanaman setiap anak petak dihitung. Perhitungan dilakukan setiap kali panen kemudian dijumlahkan untuk mendapatkan jumlah buah per anak petak total panen. Hasil perhitungan dikonversi untuk luas lahan satu hektar.

1. Berat Buah Per Anak Petak (t/ha)

Berat buah per anak petak diukur dengan cara menimbang buah tomat menggunakan timbangan gantung. Buah yang ditimbang adalah semua buah yang dipanen dari setiap anak petak. Pengukuran dilakukan setiap kali panen kemudian dijumlahkan untuk memperoleh ukuran berat buah per anak petak total panen kemudian dikonversi ke t/ha.

m. Berat Segar Berangkasan ( $\mathrm{t} / \mathrm{ha})$

Berat segar berangkasan diukur dengan cara menimbang berangkasan semua tanaman dalam setiap anak petak yang telah dipanen kemudian dikonversikan ke satuan t/ha. Pengukuran menggunakan timbangan duduk.

n. Berat Kering Berangkasan (t/ha)

Berat kering berangkasan diukur dengan cara menimbang berangkasan semua tanaman dalam setiap anak petak yang telah dipanen dan dijemur selama satu minggu kemudian dikonversikan ke satuan t/ha. Pengukuran menggunakan timbangan duduk.

o. Indeks Panen (\%)

Indeks panen dihitung dengan cara membandingkan berat bagian tanaman yang bernilai ekonomis dengan berat bagian seluruh tanaman kemudian dikonversikan ke satuan \%. Indeks panen dihitung dengan rumus.

$$
\begin{aligned}
& \mathrm{IP}=\frac{\mathrm{A}}{\mathrm{A}+\mathrm{B}} \mathrm{X} 100 \% \\
& \begin{array}{c}
\text { Keterangan } \\
\text { IP } \quad \text { : Indeks Panen (\%) }
\end{array} \\
& \text { A : Berat Buah Per Anak Petak (t/ha) } \\
& \text { B : Berat Segar Brangkasan (t/ha) }
\end{aligned}
$$

\subsection{Analisis Data}

Data hasil pengamatan kemudian dianalisis dengan menggunakan sidik ragam (Anova) Rancangan Petak Terbagi (Split Plot Design). Rata-rata perlakuan selanjutnya diuji lanjut dengan menggunakan Duncan Multiple Range Test (DMRT) dengan tingkat signifikasi 5\% sesuai petunjuk Gomez dan Gomez (1995). Analisis data menggunakan program SAS 9.1.

\section{Hasil dan Pembahasan}

3.1 Suhu Tanah

Suhu tanah cenderung menurun dari pengamatan 14 HST hingga pengamatan 42 HST. Hasil sidik ragam (Anova) menunjukkan bahwa interaksi antara jenis dan cara aplikasi pupuk kandang tidak berpengaruh nyata terhadap suhu tanah.

Jenis pupuk kandang berpengaruh nyata terhadap suhu tanah pada pengamatan 14 HST anak petak yang diberikan pupuk kandang ayam memiliki suhu tanah yang paling tinggi dan berbeda nyata dengan suhu tanah pada anak 
petak yang diberikan pupuk kandang kambing, sedangkan pada pengamatan 28 HST anak petak yang diberikan pupuk kandang sapi memiliki suhu tanah yang paling tinggi dan berbeda nyata dengan suhu tanah pada anak petak yang diberikan pupuk kandang ayam, sebaliknya pada pengamatan 42 HST anak petak yang diberikan pupuk kandang kambing memiliki suhu tanah yang paling tinggi dan berbeda nyata dengan suhu tanah pada anak petak yang diberikan pupuk kandang ayam. Cara aplikasi pupuk kandang tidak berpengaruh nyata terhadap suhu tanah setiap waktu pengamatan. Data pada Tabel 1 . menunjukkan bahwa saat pengamatan 14 HST anak petak yang diberikan pupuk kandang dengan cara aplikasi tebar, pop up maupun fertigasi memiliki suhu tanah yang sama, sedangkan pada pengamatan 28 HST dan 42 HST suhu tanah pada anak petak yang diberikan pupuk kandang dengan cara pop up cenderung lebih tinggi.

Tabel 1. Suhu Tanah

\begin{tabular}{|c|c|c|c|c|c|}
\hline \multirow{2}{*}{$\begin{array}{c}\text { Waktu } \\
\text { Pengamatan }\end{array}$} & \multirow{2}{*}{$\begin{array}{l}\text { Jenis } \\
\text { Pupuk }\end{array}$} & \multicolumn{3}{|c|}{ Cara Aplikasi } & \multirow{2}{*}{ Rerata } \\
\hline & & Tebar & Pop Up & Fertigasi & \\
\hline \multirow{4}{*}{14 HST } & Ayam & $28,7 \mathrm{ab}$ & $28,3 \mathrm{ab}$ & $28,8 \mathrm{a}$ & $28,6 \mathrm{a}$ \\
\hline & Sapi & $28,4 \mathrm{ab}$ & $28,5 \mathrm{ab}$ & $28,1 \mathrm{ab}$ & $28,3 \mathrm{ab}$ \\
\hline & Kambing & $28,0 \mathrm{~b}$ & $28,3 \mathrm{ab}$ & $28,2 \mathrm{ab}$ & $28,2 \mathrm{~b}$ \\
\hline & Rerata & $28,4 \mathrm{a}$ & $28,4 \mathrm{a}$ & $28,4 \mathrm{a}$ & $(+)$ \\
\hline \multirow{4}{*}{28 HST } & Ayam & $26,6 \mathrm{c}$ & $26,8 \mathrm{bc}$ & $26,9 a b c$ & $26,8 \mathrm{~b}$ \\
\hline & Sapi & $28,1 \mathrm{a}$ & $28,0 \mathrm{ab}$ & $27,8 \mathrm{abc}$ & $28,0 \mathrm{a}$ \\
\hline & Kambing & $27,3 \mathrm{abc}$ & $28,1 \mathrm{a}$ & $27,4 \mathrm{abc}$ & $27,6 \mathrm{a}$ \\
\hline & Rerata & $27,4 \mathrm{a}$ & $27,6 \mathrm{a}$ & $27,3 \mathrm{a}$ & $(+)$ \\
\hline \multirow{4}{*}{$42 \mathrm{HST}$} & Ayam & $26,6 \mathrm{~b}$ & $26,4 b$ & $27,1 a b$ & $26,7 \mathrm{~b}$ \\
\hline & Sapi & $27,0 \mathrm{ab}$ & $27,6 \mathrm{a}$ & $27,1 a b$ & $27,2 \mathrm{a}$ \\
\hline & Kambing & $27,0 \mathrm{ab}$ & $27,8 \mathrm{a}$ & $27,2 \mathrm{ab}$ & $27,3 \mathrm{a}$ \\
\hline & Rerata & $26,9 \mathrm{a}$ & $27,2 \mathrm{a}$ & $27,1 \mathrm{a}$ & $(+)$ \\
\hline Keterangan & $\begin{array}{l}\text { Angka pa } \\
\text { tidak berb } \\
\text { antar fakt }\end{array}$ & .9 & yang diik & engan huru & $\begin{array}{l}\text { ang sama } \\
\text { interaksi }\end{array}$ \\
\hline
\end{tabular}

\subsection{Kadar Lengas Tanah}

Kadar lengas tanah menurun dari pengamatan 14 HST hingga pengamatan 28 HST dan kembali meningkat pada 42 HST. Hasil sidik ragam (Anova) menunjukkan bahwa interaksi antara jenis dan cara aplikasi pupuk kandang tidak berpengaruh nyata terhadap kadar lengas tanah.

Jenis pupuk kandang tidak berpengaruh nyata terhadap kadar lengas tanah setiap waktu pengamatan tetapi data Tabel 2. menunjukkan bahwa pada pengamatan 14 HST dan 28 HST anak petak yang diberikan pupuk kandang ayam cenderung memiliki kadar lengas tanah yang lebih tinggi tetapi pada pengamatan 42 HST anak petak yang diberikan pupuk kandang sapi cenderung memiliki kadar lengas tanah yang lebih tinggi. Cara aplikasi pupuk kandang tidak berpengaruh nyata terhadap kadar lengas tanah waktu pengamatan 14 HST tetapi kadar lengas tanah pada anak petak yang diberikan pupuk kandang dengan cara fertigasi cenderung lebih tinggi. Saat pengamatan 28 HST, cara aplikasi pupuk kandang berpengaruh nyata terhadap kadar lengas tanah dimana kadar lengas tanah pada anak petak yang diberikan pupuk kandang dengan cara tebar paling tinggi dan berbeda nyata dengan kadar lengas tanah pada anak petak yang diberikan pupuk kandang dengan cara pup up maupun fertigasi. Saat pengamatan 42 HST, cara aplikasi pupuk kandang tidak berpengaruh nyata terhadap kadar lengas tanah tetapi kadar lengas tanah pada anak petak yang diberikan pupuk kandang dengan cara tebar cenderung masih lebih tinggi.

Tabel 2. Kadar Lengas Tanah (\%)

\begin{tabular}{cccccc}
\hline \multirow{2}{*}{$\begin{array}{c}\text { Waktu } \\
\text { Pengamatan }\end{array}$} & Jenis & \multicolumn{3}{c}{ Cara Aplikasi } & \multirow{2}{*}{ Rerata } \\
\cline { 3 - 5 } & Pupuk & Tebar & Pop Up & Fertigasi & \\
\hline \multirow{4}{*}{14 HST } & Ayam & $28,6 \mathrm{a}$ & $33,9 \mathrm{a}$ & $34,4 \mathrm{a}$ & $32,3 \mathrm{a}$ \\
& Sapi & $28,8 \mathrm{a}$ & $27,0 \mathrm{a}$ & $29,3 \mathrm{a}$ & $28,4 \mathrm{a}$ \\
& Kambing & $27,2 \mathrm{a}$ & $26,9 \mathrm{a}$ & $30,6 \mathrm{a}$ & $28,2 \mathrm{a}$ \\
\cline { 2 - 5 } & Rerata & $28,2 \mathrm{a}$ & $29,3 \mathrm{a}$ & $31,4 \mathrm{a}$ & $(-)$ \\
\hline \multirow{4}{*}{$28 \mathrm{HST}$} & Ayam & $23,7 \mathrm{abc}$ & $21,8 \mathrm{bc}$ & $23,9 \mathrm{ab}$ & $23,2 \mathrm{a}$ \\
& Sapi & $23,3 \mathrm{abc}$ & $21,9 \mathrm{bc}$ & $22,8 \mathrm{abc}$ & $22,7 \mathrm{a}$ \\
& Kambing & $25,1 \mathrm{a}$ & $21,8 \mathrm{bc}$ & $21,2 \mathrm{c}$ & $22,7 \mathrm{a}$ \\
\cline { 2 - 5 } $42 \mathrm{HST}$ & Rerata & $24,0 \mathrm{a}$ & $21,8 \mathrm{~b}$ & $22,7 \mathrm{~b}$ & $(-)$ \\
& Ayam & $29,5 \mathrm{a}$ & $29,9 \mathrm{a}$ & $28,0 \mathrm{a}$ & $29,1 \mathrm{a}$ \\
& Sapi & $36,4 \mathrm{a}$ & $31,0 \mathrm{a}$ & $34,0 \mathrm{a}$ & $33,8 \mathrm{a}$ \\
& Kambing & $28,9 \mathrm{a}$ & $31,1 \mathrm{a}$ & $29,2 \mathrm{a}$ & $29,7 \mathrm{a}$ \\
\cline { 2 - 5 } & Rerata & $31,6 \mathrm{a}$ & $30,7 \mathrm{a}$ & $30,4 \mathrm{a}$ & $(-)$
\end{tabular}

Keterangan: Angka pada baris dan kolom yang diikuti dengan huruf yang sama tidak berbeda nyata menurut uji DMRT $\alpha 5 \%$. (-) : Tidak terjadi interaksi antar faktor

\subsection{Berat Volume Tanah}

Hasil sidik ragam (Anova) menunjukkan bahwa interaksi antara jenis dan cara aplikasi pupuk kandang tidak berpengaruh nyata terhadap berat volume tanah.

Jenis pupuk kandang berpengaruh nyata terhadap berat volume tanah saat pengamatan 14 HST dimana anak petak yang diberikan pupuk kandang kambing memiliki berat volume tanah yang paling tinggi dan berbeda nyata dengan berat volume tanah pada anak petak yang diberikan pupuk kandang ayam, sedangkan pada pengamatan selanjutnya jenis pupuk kandang tidak berpengaruh nyata terhadap berat volume tanah tetapi data Tabel 3 . menunjukkan bahwa pada pengamatan 28 HST maupun 42 HST, anak petak yang diberikan pupuk kandang kambing masih cenderung memiliki berat volume tanah yang lebih tinggi. Cara aplikasi pupuk kandang tidak berpengaruh nyata terhadap berat volume tanah setiap waktu pengamatan. Saat pengamatan 14 HST berat volume tanah pada anak petak yang diberikan pupuk kandang dengan cara fertigasi cenderung lebih tinggi tetapi saat pengamatan 28 HST dan 42 HST berat volume tanah pada anak petak yang diberikan pupuk kandang dengan cara tebar cenderung lebih tinggi.

Tabel 3. Berat Volume Tanah $\left(\mathrm{g} / \mathrm{cm}^{3}\right)$

\begin{tabular}{cccccc}
\hline Waktu & Jenis & \multicolumn{3}{c}{ Cara Aplikasi } & \multirow{2}{*}{ Rerata } \\
\cline { 3 - 5 } Pengamatan & Pupuk & Tebar & Pop Up & Fertigasi & \\
\hline \multirow{4}{*}{$14 \mathrm{HST}$} & Ayam & $1,43 \mathrm{~b}$ & $1,51 \mathrm{ab}$ & $1,51 \mathrm{ab}$ & $1,48 \mathrm{~b}$ \\
& Sapi & $1,53 \mathrm{ab}$ & $1,45 \mathrm{ab}$ & $1,55 \mathrm{ab}$ & $1,51 \mathrm{ab}$ \\
& Kambing & $1,60 \mathrm{a}$ & $1,53 \mathrm{ab}$ & $1,58 \mathrm{a}$ & $1,57 \mathrm{a}$ \\
\cline { 2 - 5 } $28 \mathrm{HST}$ & Rerata & $1,52 \mathrm{a}$ & $1,50 \mathrm{a}$ & $1,55 \mathrm{a}$ & $(-)$ \\
\hline & Ayam & $1,61 \mathrm{a}$ & $1,60 \mathrm{a}$ & $1,55 \mathrm{a}$ & $1,59 \mathrm{a}$ \\
& Sapi & $1,60 \mathrm{a}$ & $1,61 \mathrm{a}$ & $1,56 \mathrm{a}$ & $1,59 \mathrm{a}$ \\
& Kambing & $1,61 \mathrm{a}$ & $1,58 \mathrm{a}$ & $1,62 \mathrm{a}$ & $1,60 \mathrm{a}$ \\
\cline { 2 - 5 } $42 \mathrm{HST}$ & Rerata & $1,61 \mathrm{a}$ & $1,59 \mathrm{a}$ & $1,58 \mathrm{a}$ & $(-)$ \\
\cline { 2 - 5 } & Ayam & $1,50 \mathrm{a}$ & $1,41 \mathrm{a}$ & $1,47 \mathrm{a}$ & $1,46 \mathrm{a}$ \\
& Sapi & $1,59 \mathrm{a}$ & $1,52 \mathrm{a}$ & $1,44 \mathrm{a}$ & $1,52 \mathrm{a}$ \\
& Kambing & $1,59 \mathrm{a}$ & $1,52 \mathrm{a}$ & $1,53 \mathrm{a}$ & $1,54 \mathrm{a}$ \\
\cline { 2 - 5 } Keterangan : & Rerata & $1,56 \mathrm{a}$ & $1,48 \mathrm{a}$ & $1,48 \mathrm{a}$ & $(-)$ \\
& Angka pada baris dan kolom yang diikuti dengan huruf yang sama \\
& tidak berbeda nyata menurut uji DMRT $\alpha$ 5\%. (-) : Tidak terjadi \\
& interaksi antar faktor & & &
\end{tabular}

\subsection{Tinggi Tanaman}

Tanaman bertambah tinggi sejak pengamatan awal hingga pengamatan terakhir. Hasil sidik ragam (Anova) menunjukkan bahwa interaksi antara jenis dan cara aplikasi pupuk kandang tidak berpengaruh nyata terhadap tinggi tanaman.

Tabel 4. Tinggi Tanaman $(\mathrm{cm})$

\begin{tabular}{|c|c|c|c|c|c|}
\hline \multirow{2}{*}{$\begin{array}{c}\text { Waktu } \\
\text { Pengamatan }\end{array}$} & \multirow{2}{*}{$\begin{array}{l}\text { Jenis } \\
\text { Pupuk }\end{array}$} & \multicolumn{3}{|c|}{ Cara Aplikasi } & \multirow{2}{*}{ Rerata } \\
\hline & & Tebar & Pop Up & Fertigasi & \\
\hline \multirow{4}{*}{$14 \mathrm{HST}$} & Ayam & $6,8 \mathrm{abc}$ & $6,1 \mathrm{bc}$ & $7,5 \mathrm{ab}$ & $6,8 \mathrm{~b}$ \\
\hline & Sapi & $8,2 \mathrm{ab}$ & $5,2 \mathrm{c}$ & $7,1 \mathrm{abc}$ & $6,8 \mathrm{~b}$ \\
\hline & Kambing & $8,2 \mathrm{ab}$ & $8,4 \mathrm{a}$ & $8,3 \mathrm{ab}$ & $8,3 \mathrm{a}$ \\
\hline & Rerata & $7,7 \mathrm{a}$ & $6,6 \mathrm{a}$ & $7,6 \mathrm{a}$ & $(-)$ \\
\hline \multirow{4}{*}{$28 \mathrm{HST}$} & Ayam & $21,4 \mathrm{abc}$ & $18,6 \mathrm{c}$ & $22,0 \mathrm{abc}$ & $20,7 \mathrm{~b}$ \\
\hline & Sapi & $23,5 \mathrm{abc}$ & $19,5 \mathrm{bc}$ & $23,3 \mathrm{abc}$ & $22,1 \mathrm{ab}$ \\
\hline & Kambing & $25,7 \mathrm{a}$ & $21,1 \mathrm{abc}$ & $24,1 \mathrm{ab}$ & $23,6 \mathrm{a}$ \\
\hline & Rerata & $23,5 \mathrm{a}$ & $19,7 \mathrm{~b}$ & $23,1 \mathrm{a}$ & $(-)$ \\
\hline \multirow{4}{*}{42 HST } & Ayam & $63,4 \mathrm{ab}$ & $51,9 \mathrm{c}$ & $62,8 \mathrm{ab}$ & $59,4 \mathrm{a}$ \\
\hline & Sapi & $63,1 \mathrm{ab}$ & $59,3 \mathrm{bc}$ & $64,2 \mathrm{ab}$ & $62,2 \mathrm{a}$ \\
\hline & Kambing & $66,5 \mathrm{ab}$ & $54,4 \mathrm{c}$ & $69,3 \mathrm{a}$ & $63,4 \mathrm{a}$ \\
\hline & Rerata & $64,3 \mathrm{a}$ & $55,2 \mathrm{~b}$ & $65,4 \mathrm{a}$ & $(-)$ \\
\hline ter & $\begin{array}{l}\text { Angka pac } \\
\text { tidak berb } \\
\text { interaksi a }\end{array}$ & aktor & yang di & engan hu & $\begin{array}{l}\text { ang sama } \\
\mathrm{k} \text { terjad }\end{array}$ \\
\hline
\end{tabular}

Jenis pupuk kandang berpengaruh nyata terhadap tinggi tanaman saat pengamatan 14 HST dan 28 HST dimana saat 14 HST tanaman yang diberikan pupuk kandang kambing paling tinggi dan berbeda nyata dengan tinggi tanaman yang diberikan pupuk kandang ayam maupun sapi, saat 28 HST tanaman yang diberikan pupuk kandang kambing tetap paling tinggi dan berbeda nyata dengan tinggi tanaman yang diberikan pupuk kandang ayam tetapi sudah tidak nyata berbeda dengan tinggi tanaman yang diberikan pupuk kandang sapi. Pada pengamatan 42 HST tinggi tanaman yang diberikan ketiga jenis pupuk kandang tidak saling berbeda nyata tetapi tanaman yang diberikan pupuk kandang kambing tetap cenderung lebih tinggi.

Cara aplikasi pupuk kandang tidak berpengaruh nyata terhadap tinggi tanaman waktu pengamatan 14 HST tetapi tanaman yang diberikan pupuk kandang dengan cara tebar cenderung lebih tinggi, selanjutnya saat pengamatan $28 \mathrm{HST}$, cara aplikasi pupuk kandang berpengaruh nyata terhadap tinggi tanaman dimana tanaman yang diberikan pupuk kandang dengan cara tebar paling tinggi dan berbeda nyata dengan tinggi tanaman yang diberikan pupuk kandang dengan cara pop up tetapi tidak berbeda nyata dengan tinggi tanaman yang diberikan pupuk kandang dengan cara fertigasi. Saat pengamatan 42 HST, cara aplikasi pupuk kandang juga berpengaruh nyata terhadap tinggi tanaman dimana tanaman yang diberikan pupuk kandang dengan cara fertigasi paling tinggi dan berbeda nyata dengan tinggi tanaman yang diberikan pupuk kandang dengan cara pop up tetapi tidak berbeda nyata dengan tinggi tanaman yang diberikan pupuk kandang dengan cara tebar. 


\subsection{Diameter Batang}

Batang bertambah besar pada pengamatan awal hingga pengamatan terakhir. Hasil sidik ragam (Anova) menunjukkan tidak terjadi interaksi. Jenis pupuk dan cara aplikasi tidak berpengaruh nyata pada diameter batang setiap waktu pengamatan, tetapi pada Tabel 5. menunjukkan bahwa pada waktu pengamatan 14 HST dan 42 HST, ketiga jenis pupuk tersebut memberikan diameter batang yang sama besar namun pada waktu pengamatan 28 HST jenis pupuk kambing menghasilkan diameter batang yang cenderung lebih besar di banding dengan jenis pupuk ayam dan sapi.

Ketiga cara aplikasi sama-sama memberikan diameter batang yang lebih besar pada waktu pengamatan 14 HST. namun cara aplikasi fertigasi lebih memebrikan diamter batang yang lebih besar dibandingkan kedua cara aplikasi lainnya. Pada waktu pengamatan 42 HST, cara aplikasi tebar dan fertigasi memberikan diameter batang yang lebih besar dibandingkan cara aplikasi po up.

\begin{tabular}{|c|c|c|c|c|c|}
\hline \multirow{2}{*}{$\begin{array}{c}\text { Waktu } \\
\text { Pengamatan }\end{array}$} & \multirow{2}{*}{ Jenis Pupuk } & \multicolumn{3}{|c|}{ Cara Aplikasi } & \multirow{2}{*}{ Rerata } \\
\hline & & Tebar & Pop Up & Fertigasi & \\
\hline \multirow{4}{*}{$14 \mathrm{HST}$} & Ayam & $0,62 \mathrm{bc}$ & $0,63 \mathrm{bc}$ & $0,68 \mathrm{a}$ & $0,65 \mathrm{a}$ \\
\hline & Sapi & $0,61 \mathrm{c}$ & $0,66 \mathrm{ab}$ & $0,68 \mathrm{a}$ & $0,65 \mathrm{a}$ \\
\hline & Kambing & $0,66 a b$ & $0,61 \mathrm{bc}$ & $0,68 \mathrm{a}$ & $0,65 \mathrm{a}$ \\
\hline & Rerata & $0,63 \mathrm{~b}$ & $0,64 \mathrm{~b}$ & $0,68 \mathrm{a}$ & $(+)$ \\
\hline \multirow{4}{*}{28 HST } & Ayam & $0,76 \mathrm{ab}$ & $0,72 \mathrm{~b}$ & $0,80 \mathrm{ab}$ & $0,76 \mathrm{a}$ \\
\hline & Sapi & $0,80 a b$ & $0,74 \mathrm{ab}$ & $0,79 \mathrm{ab}$ & $0,78 \mathrm{a}$ \\
\hline & Kambing & $0,75 \mathrm{ab}$ & $0,77 \mathrm{ab}$ & $0,82 \mathrm{a}$ & $0,78 \mathrm{a}$ \\
\hline & Rerata & $0,77 \mathrm{ab}$ & $0,74 \mathrm{~b}$ & $0,80 \mathrm{a}$ & $(-)$ \\
\hline \multirow{4}{*}{42 HST } & Ayam & $0,82 \mathrm{a}$ & $0,84 \mathrm{a}$ & $0,90 \mathrm{a}$ & $0,85 \mathrm{a}$ \\
\hline & Sapi & $0,91 \mathrm{a}$ & $0,86 \mathrm{a}$ & $0,88 \mathrm{a}$ & $0,88 \mathrm{a}$ \\
\hline & Kambing & $0,93 \mathrm{a}$ & $0,89 \mathrm{a}$ & $0,89 \mathrm{a}$ & $0,90 \mathrm{a}$ \\
\hline & Rerata & $0,88 \mathrm{a}$ & $0,86 \mathrm{a}$ & $0,89 \mathrm{a}$ & $(--)$ \\
\hline
\end{tabular}

Keterangan: Angka pada baris dan kolom yang diikuti dengan huruf yang sama tidak berbeda nyata menurut uji DMRT $\alpha 5 \% .(+)$ : Terjadi interaksi antar faktor $(-)$ : Tidak terjadi interaksi antar faktor

\subsection{Luas Daun}

Hasil sidik ragam (Anova) menunjukkan bahwa interaksi antara jenis dan cara aplikasi pupuk kandang tidak berpengaruh nyata terhadap luas daun.

Jenis pupuk kandang tidak berpengaruh nyata terhadap luas daun tetapi data Tabel 6. menunjukkan bahwa permukaan daun tanaman yang diberikan pupuk kandang ayam cenderung lebih luas sedangkan permukaan daun tanaman yang diberikan pupuk kandang kambing paling sempit. Cara aplikasi pupuk kandang tidak berpengaruh nyata terhadap luas daun tetapi permukaan daun tanaman yang diberikan pupuk kandang dengan cara pop up cenderung lebih luas sedangkan permukaan daun tanaman yang diberikan pupuk kandang dengan cara fertigasi paling sempit.

Tabel 6. Luas Daun $\left(\mathrm{cm}^{2}\right)$

\begin{tabular}{clllc}
\hline \multirow{2}{*}{ Jenis Pupuk } & \multicolumn{3}{c}{ Cara Aplikasi } & \multirow{2}{*}{ Rerata } \\
\cline { 2 - 4 } & Tebar & Pop Up & Fertigasi & \\
\hline Ayam & $2534,7 \mathrm{ab}$ & $2113,0 \mathrm{c}$ & $2148,0 \mathrm{c}$ & $2265,2 \mathrm{a}$ \\
Sapi & $1928,0 \mathrm{~cd}$ & $1901,0 \mathrm{~cd}$ & $2042,3 \mathrm{~cd}$ & $1957,1 \mathrm{a}$ \\
Kambing & $1655,3 \mathrm{~d}$ & $2547,0 \mathrm{a}$ & $1641,3 \mathrm{~d}$ & $1947,9 \mathrm{a}$ \\
\hline Rerata & $2039,3 \mathrm{a}$ & $2187,0 \mathrm{a}$ & $1943,9 \mathrm{a}$ & $(-)$ \\
\hline Keterangan : & Angka pada baris dan kolom yang diikuti dengan huruf yang sama \\
& tidak berbeda nyata menurut uji DMRT $\alpha$ 5\%. (-) : Tidak terjadi \\
& interaksi antar faktor
\end{tabular}

\subsection{Diameter Buah}

Hasil sidik ragam (Anova) menunjukkan bahwa interaksi antara jenis dan cara aplikasi pupuk kandang tidak berpengaruh nyata terhadap diameter buah.

Jenis pupuk kandang tidak berpengaruh nyata terhadap diameter buah tetapi data Tabel 7. menunjukkan bahwa buah dari tanaman yang diberikan pupuk kandang ayam cenderung lebih besar dibandingkan dengan buah dari tanaman yang diberikan pupuk kandang sapi maupun kambing. Cara aplikasi pupuk kandang tidak berpengaruh nyata terhadap diameter buah tetapi buah tanaman yang diberikan pupuk kandang dengan cara tebar dan fertigasi cenderung lebih besar dibandingkan dengan buah dari tanaman yang diberikan pupuk kandang dengan cara pop up.

Tabel 7. Diameter Buah $(\mathrm{cm})$

\begin{tabular}{ccccc}
\hline \multirow{2}{*}{ Jenis Pupuk } & \multicolumn{3}{c}{ Cara Aplikasi } & \multirow{2}{*}{ Rerata } \\
\cline { 2 - 4 } & Tebar & Pop Up & Fertigasi & \\
\hline Ayam & $4,2 \mathrm{a}$ & $4,0 \mathrm{a}$ & $4,1 \mathrm{a}$ & $4,1 \mathrm{a}$ \\
Sapi & $4,0 \mathrm{a}$ & $4,1 \mathrm{a}$ & $4,0 \mathrm{a}$ & $4,0 \mathrm{a}$ \\
Kambing & $4,1 \mathrm{a}$ & $4,0 \mathrm{a}$ & $4,1 \mathrm{a}$ & $4,0 \mathrm{a}$ \\
\hline Rerata & $4,1 \mathrm{a}$ & $4,0 \mathrm{a}$ & $4,1 \mathrm{a}$ & $(-)$ \\
\hline Keterangan: & Angka pada baris dan kolom yang diikuti dengan huruf yang sama
\end{tabular}
tidak berbeda nyata menurut uji DMRT $\alpha 5 \%$. (-) : Tidak terjadi interaksi antar faktor

\subsection{Berat Per Buah}

Hasil sidik ragam (Anova) menunjukkan bahwa interaksi antara jenis dan cara aplikasi pupuk kandang tidak berpengaruh nyata terhadap berat per buah.

Jenis pupuk kandang berpengaruh nyata terhadap berat per buah dimana setiap buah dari tanaman yang diberikan pupuk kandang ayam paling berat dan berbeda nyata dengan berat per buah dari tanaman yang diberikan pupuk kandang sapi maupun berat per buah dari tanaman yang diberikan pupuk kandang kambing yang menghasilkan berat per buah paling ringan. Cara aplikasi pupuk kandang tidak berpengaruh nyata terhadap berat per buah tetapi setiap buah dari tanaman yang diberikan pupuk kandang dengan cara pop up cenderung lebih berat sedangkan setiap buah dari tanaman yang diberikan pupuk kandang dengan cara fertigasi paling ringan.

\section{Tabel 8. Berat Per Buah (g)}

\begin{tabular}{cllll}
\hline \multirow{2}{*}{ Jenis Pupuk } & \multicolumn{3}{c}{ Cara Aplikasi } & \multirow{2}{*}{ Rerata } \\
\cline { 2 - 4 } & \multicolumn{1}{c}{ Tebar } & Pop Up & Fertigasi & \\
\hline Ayam & $30,2 \mathrm{a}$ & $29,6 \mathrm{a}$ & $23,3 \mathrm{ab}$ & $27,7 \mathrm{a}$ \\
Sapi & $19,7 \mathrm{~b}$ & $22,5 \mathrm{ab}$ & $23,8 \mathrm{ab}$ & $22,0 \mathrm{~b}$ \\
Kambing & $23,9 \mathrm{ab}$ & $22,0 \mathrm{ab}$ & $23,2 \mathrm{ab}$ & $23,0 \mathrm{~b}$ \\
\hline Rerata & $24,6 \mathrm{a}$ & $24,7 \mathrm{a}$ & $23,4 \mathrm{a}$ & $(-)$ \\
\hline Keterangan : & Angka pada baris dan kolom yang diikuti dengan huruf yang sama \\
& tidak berbeda nyata menurut uji DMRT $\alpha$ 5\%. (-) : Tidak terjadi \\
& interaksi antar faktor
\end{tabular}

\subsection{Jumlah Buah Per Tanaman}

Hasil sidik ragam (Anova) menunjukkan bahwa interaksi antara jenis dan cara aplikasi pupuk kandang tidak berpengaruh nyata terhadap jumlah buah per tanaman.

Jenis pupuk kandang berpengaruh nyata terhadap jumlah buah per tanaman dimana jumlah buah dari tanaman yang diberikan pupuk kandang kambing paling banyak dan berbeda nyata dengan jumlah buah dari tanaman yang diberikan pupuk kandang ayam tetapi tidak berbeda nyata dengan jumlah buah dari tanaman yang diberikan pupuk kandang sapi. Cara aplikasi pupuk kandang tidak berpengaruh nyata terhadap jumlah buah per tanaman tetapi buah dari setiap tanaman yang diberikan pupuk kandang dengan cara fertigasi cenderung lebih banyak sedangkan buah dari setiap tanaman yang diberikan pupuk kandang dengan cara pop up paling sedikit.

\section{Tabel 9. Jumlah Buah Per Tanaman}

\begin{tabular}{ccccc}
\hline \multirow{2}{*}{ Jenis Pupuk } & \multicolumn{3}{c}{ Cara Aplikasi } & \multirow{2}{*}{ Rerata } \\
\cline { 2 - 4 } & Tebar & Pop Up & Fertigasi & \\
\hline Ayam & $41,1 \mathrm{a}$ & $41,0 \mathrm{a}$ & $44,6 \mathrm{a}$ & $42,2 \mathrm{~b}$ \\
Sapi & $47,1 \mathrm{a}$ & $46,6 \mathrm{a}$ & $46,6 \mathrm{a}$ & $46,8 \mathrm{a}$ \\
Kambing & $47,9 \mathrm{a}$ & $47,6 \mathrm{a}$ & $47,1 \mathrm{a}$ & $47,5 \mathrm{a}$ \\
\hline Rerata & $45,4 \mathrm{a}$ & $45,1 \mathrm{a}$ & $46,1 \mathrm{a}$ & $(-)$ \\
\hline Keterangan : & Angka pada baris dan kolom yang diikuti dengan huruf yang sama \\
& tidak berbeda nyata menurut uji DMRT $\alpha$ 5\%. (-) : Tidak terjadi \\
& interaksi antar faktor
\end{tabular}

\subsection{Berat Buah Per Tanaman}

Hasil sidik ragam (Anova) menunjukkan bahwa interaksi antara jenis dan cara aplikasi pupuk kandang tidak berpengaruh nyata terhadap berat buah pertanaman.

\section{Tabel 10. Berat Buah Per Tanaman (g)}

\begin{tabular}{ccccc}
\hline \multirow{2}{*}{ Jenis Pupuk } & \multicolumn{3}{c}{ Cara Aplikasi } & \multirow{2}{*}{ Rerata } \\
\cline { 2 - 4 } & Tebar & Pop Up & Fertigasi & \\
\hline Ayam & $1.234 \mathrm{a}$ & $1.214 \mathrm{a}$ & $1.040 \mathrm{a}$ & $1.163 \mathrm{a}$ \\
Sapi & $927 \mathrm{a}$ & $1.051 \mathrm{a}$ & $1.114 \mathrm{a}$ & $1.031 \mathrm{a}$ \\
Kambing & $1.147 \mathrm{a}$ & $1.047 \mathrm{a}$ & $1.087 \mathrm{a}$ & $1.094 \mathrm{a}$ \\
\hline Rerata & $1.103 \mathrm{a}$ & $1.104 \mathrm{a}$ & $1.080 \mathrm{a}$ & $(-)$ \\
\hline Keterangan : & Angka pada baris dan kolom yang diikuti dengan huruf yang sama \\
& $\begin{array}{l}\text { tidak berbeda nyata menurut uji DMRT } \alpha \text { 5\%. (-) : Tidak terjadi } \\
\text { interaksi antar faktor }\end{array}$
\end{tabular}

Jenis pupuk kandang tidak berpengaruh nyata terhadap berat buah per tanaman tetapi data Tabel 10. menunjukkan bahwa buah setiap tanaman yang diberikan pupuk kandang ayam cenderung lebih berat sedangkan buah setiap tanaman yang diberikan pupuk kandang sapi paling ringan. Cara aplikasi pupuk kandang tidak berpengaruh nyata terhadap berat buah per tanaman tetapi buah dari setiap tanaman yang diberikan pupuk kandang dengan cara pop up cenderung lebih berat sedangkan buah dari setiap tanaman yang diberikan pupuk kandang dengan cara fertigasi paling ringan.

\subsection{Jumlah Buah Per Anak Petak}

Hasil sidik ragam (Anova) menunjukkan bahwa interaksi antara jenis dan cara aplikasi pupuk kandang tidak berpengaruh nyata terhadap jumlah buah per anak petak dimana tanaman yang diberikan pupuk kandang ayam dengan cara fertigasi menghasilkan buah setiap anak petak paling banyak yang berbeda nyata dengan jumlah buah per anak petak dari tanaman yang diberikan pupuk kandang yang sama dengan cara tebar, jumlah buah per anak petak dari tanaman yang diberikan pupuk kandang sapi dengan cara fertigasi dan jumlah 
buah per anak petak dari tanaman yang diberikan pupuk kandang kambing dengan cara popo up maupun fertigasi tetapi tidak berbeda nyata dengan jumlah buah per anak petak dari tanaman yang diberikan perlakuan dengan kombinasi yang lainnya.

Tabel 11. Jumlah Buah Per Anak Petak

\begin{tabular}{clccc}
\hline \multirow{2}{*}{ Jenis Pupuk } & \multicolumn{3}{c}{ Cara Aplikasi } & \multirow{2}{*}{ Rerata } \\
\cline { 2 - 4 } & \multicolumn{1}{c}{ Tebar } & Pop Up & Fertigasi & \\
\hline Ayam & $1.654 .444 \mathrm{c}$ & $3.354 .444 \mathrm{a}$ & $3.487 .778 \mathrm{a}$ & $2.832 .222 \mathrm{a}$ \\
Sapi & $3.096 .667 \mathrm{a}$ & $2.943 .333 \mathrm{ab}$ & $1.782 .222 \mathrm{c}$ & $2.607 .407 \mathrm{ab}$ \\
Kambing & $2.602 .222 \mathrm{abc}$ & $2.001 .111 \mathrm{bc}$ & $1.633 .333 \mathrm{c}$ & $2.078 .889 \mathrm{~b}$ \\
\hline Rerata & $2.451 .111 \mathrm{a}$ & $2.766 .296 \mathrm{a}$ & $2.301 .111 \mathrm{a}$ & $(+)$ \\
\hline Keterangan : & $\begin{array}{l}\text { Angka pada baris dan kolom yang diikuti dengan huruf yang sama } \\
\end{array}$ & $\begin{array}{l}\text { tidak berbeda nyata menurut uji DMRT } \alpha \text { 5\%. }(+) \text { : Terjadi interaksi } \\
\text { antar faktor }\end{array}$ &
\end{tabular}

Jenis pupuk kandang berpengaruh nyata terhadap jumlah buah per anak petak dimana jumlah buah setiap anak petak dari tanaman yang diberikan pupuk kandang ayam paling banyak dan berbeda nyata dengan jumlah buah per anak petak dari tanaman yang diberikan pupuk kandang kambing tetapi tidak berbeda nyata dengan jumlah buah per anak petak dari tanaman yang diberikan pupuk kandang sapi. Cara aplikasi pupuk kandang tidak berpengaruh nyata terhadap jumlah buah per anak petak tetapi buah setiap anak petak dari tanaman yang diberikan pupuk kandang dengan cara pop up cenderung lebih banyak sedangkan buah setiap petak dari tanaman yang diberikan pupuk kandang dengan cara fertigasi paling sedikit.

\subsection{Berat Buah Per Anak Petak}

Hasil tomat terus meningkat dari panen pertama hingga panen yang ketiga. Hasil sidik ragam (Anova) menunjukkan bahwa interaksi antara jenis dan cara aplikasi pupuk kandang tidak berpengaruh nyata terhadap berat buah per anak petak.

Jenis pupuk kandang tidak berpengaruh nyata terhadap berat buah per anak petak setiap kali panen hingga total panen tetapi data Tabel 12. Menunjukkan bahwa buah hasil panen setiap anak petak saat panen I, panen II dan total panen dari tanaman yang diberikan pupuk kandang kambing cenderung lebih berat sedangkan buah setiap anak petak dari tanaman yang diberikan pupuk kandang ayam paling ringan sedangkan saat panen III buah hasil panen setiap anak petak dari tanaman yang diberikan pupuk kandang sapi cenderung lebih berat sedangkan buah setiap anak petak dari tanaman yang diberikan pupuk kandang ayam tetap paling ringan.

Cara aplikasi pupuk kandang tidak berpengaruh nyata terhadap berat buah per anak petak setiap kali panen maupun total panen. Saat panen I, tanaman yang diberikan pupuk kandang dengan cara fertigasi menghasilkan buah setiap anak petak yang cenderung lebih berat sedangkan buah setiap petak dari tanaman yang diberikan pupuk kandang dengan cara tebar paling ringan. Saat panen II, tanaman yang diberikan pupuk kandang dengan cara tebar menghasilkan buah setiap anak petak yang cenderung lebih berat sedangkan buah setiap petak dari tanaman yang diberikan pupuk kandang dengan cara fertigasi paling ringan. Saat panen III, tanaman yang diberikan pupuk kandang dengan cara pop up menghasilkan buah setiap anak petak yang cenderung lebih berat sedangkan buah setiap petak dari tanaman yang diberikan pupuk kandang dengan cara fertigasi paling ringan. Pada perhitungan total panen, tanaman yang diberikan pupuk kandang dengan cara pop up menghasilkan buah setiap anak petak yang cenderung lebih berat sedangkan buah setiap petak dari tanaman yang diberikan pupuk kandang dengan cara fertigasi paling ringan.

Tabel 12. Berat Buah Per Anak Petak (t/ha)

\begin{tabular}{cccccc}
\hline Waktu & Jenis & \multicolumn{3}{c}{ Cara Aplikasi } & \multirow{2}{*}{ Rerata } \\
\cline { 3 - 5 } Pengamatan & Pupuk & Tebar & Pop Up & Fertigasi & \\
\hline \multirow{5}{*}{ Panen I } & Ayam & $5,867 \mathrm{a}$ & $7,536 \mathrm{a}$ & $7,780 \mathrm{a}$ & $7,061 \mathrm{a}$ \\
& Sapi & $7,849 \mathrm{a}$ & $7,425 \mathrm{a}$ & $7,236 \mathrm{a}$ & $7,503 \mathrm{a}$ \\
& Kambing & $8,314 \mathrm{a}$ & $7,780 \mathrm{a}$ & $8,959 \mathrm{a}$ & $8,351 \mathrm{a}$ \\
\cline { 2 - 5 } Panen II & Rerata & $7,343 \mathrm{a}$ & $7,580 \mathrm{a}$ & $7,992 \mathrm{a}$ & $(-)$ \\
\hline \multirow{5}{*}{ Panen III } & Ayam & $18,894 \mathrm{a}$ & $22,781 \mathrm{a}$ & $20,671 \mathrm{a}$ & $20,782 \mathrm{a}$ \\
& Sapi & $26,227 \mathrm{a}$ & $22,670 \mathrm{a}$ & $18,562 \mathrm{a}$ & $22,486 \mathrm{a}$ \\
& Kambing & $22,781 \mathrm{a}$ & $20,671 \mathrm{a}$ & $26,227 \mathrm{a}$ & $23,226 \mathrm{a}$ \\
\cline { 2 - 5 } & Rerata & $22,634 \mathrm{a}$ & $22,041 \mathrm{a}$ & $21,820 \mathrm{a}$ & $(-)$ \\
\hline \multirow{5}{*}{ Total Panen } & Ayam & $33,174 \mathrm{a}$ & $44,225 \mathrm{a}$ & $34,748 \mathrm{a}$ & $37,382 \mathrm{a}$ \\
& Sapi & $40,393 \mathrm{a}$ & $40,171 \mathrm{a}$ & $36,528 \mathrm{a}$ & $39,030 \mathrm{a}$ \\
& Kambing & $39,226 \mathrm{a}$ & $40,171 \mathrm{a}$ & $36,528 \mathrm{a}$ & $38,642 \mathrm{a}$ \\
\cline { 2 - 5 } & Rerata & $37,598 \mathrm{a}$ & $41,522 \mathrm{a}$ & $35,935 \mathrm{a}$ & $(-)$ \\
\hline & Ayam & $57,935 \mathrm{a}$ & $74,543 \mathrm{a}$ & $63,199 \mathrm{a}$ & $65,226 \mathrm{a}$ \\
& Sapi & $74,468 \mathrm{a}$ & $70,265 \mathrm{a}$ & $62,326 \mathrm{a}$ & $69,020 \mathrm{a}$ \\
& Kambing & $70,322 \mathrm{a}$ & $68,621 \mathrm{a}$ & $71,714 \mathrm{a}$ & $70,219 \mathrm{a}$ \\
\cline { 2 - 5 } & Rerata & $67,575 \mathrm{a}$ & $71,143 \mathrm{a}$ & $65,746 \mathrm{a}$ & $(-)$
\end{tabular}

Keterangan: Angka pada baris dan kolom yang diikuti dengan huruf yang sama tidak berbeda nyata menurut uji DMRT $\alpha 5 \%$. (-) : Tidak terjadi interaksi antar faktor

\subsection{Berat Segar Berangkasan}

Hasil sidik ragam (Anova) menunjukkan bahwa interaksi antara jenis dan cara aplikasi pupuk kandang tidak berpengaruh nyata terhadap berat segar berangkasan.

Jenis pupuk kandang tidak berpengaruh nyata terhadap berat segar berangkasan tetapi data Tabel 13. menunjukkan bahwa berangkasan segar tanaman yang diberikan pupuk kandang sapi cenderung lebih berat sedangkan berangkasan segar tanaman yang diberikan pupuk kandang kambing paling ringan. Cara aplikasi pupuk kandang tidak berpengaruh nyata terhadap berat segar berangkasan tetapi berangkasan segar dari tanaman yang diberikan pupuk kandang dengan cara pop up cenderung lebih berat sedangkan berangkasan segar dari tanaman yang diberikan pupuk kandang dengan cara fertigasi paling ringan.

Tabel 13. Berat Segar Berangkasan (t/ha)

\begin{tabular}{|c|c|c|c|c|}
\hline \multirow{2}{*}{ Jenis Pupuk } & \multicolumn{3}{|c|}{ Cara Aplikasi } & \multirow{2}{*}{ Rerata } \\
\hline & Tebar & Pop Up & Fertigasi & \\
\hline Ayam & $45,111 \mathrm{a}$ & $43,333 \mathrm{a}$ & $41,000 \mathrm{a}$ & $43,148 \mathrm{a}$ \\
\hline Sapi & 42,333 a & $45,444 \mathrm{a}$ & $44,222 \mathrm{a}$ & $44,000 \mathrm{a}$ \\
\hline Kambing & $41,111 \mathrm{a}$ & $44,667 \mathrm{a}$ & $40,333 \mathrm{a}$ & $42,037 \mathrm{a}$ \\
\hline Rerata & $42,852 \mathrm{a}$ & $44,481 \mathrm{a}$ & $41,852 \mathrm{a}$ & $(-)$ \\
\hline Keterangan : & $\begin{array}{l}\text { tidak berbeda } \\
\text { interaksi antar } \mathrm{f}\end{array}$ & n kolom ya & kuti dengan & yang sam \\
\hline
\end{tabular}

\subsection{Berat Kering Berangkasan}

Hasil sidik ragam (Anova) menunjukkan bahwa interaksi antara jenis dan cara aplikasi pupuk kandang tidak berpengaruh nyata terhadap berat kering berangkasan.

Jenis pupuk kandang tidak berpengaruh nyata terhadap berat kering berangkasan tetapi data Tabel 14. menunjukkan bahwa berangkasan kering tanaman yang diberikan pupuk kandang sapi cenderung lebih berat sedangkan berangkasan kering tanaman yang diberikan pupuk kandang kambing paling ringan. Cara aplikasi pupuk kandang tidak berpengaruh nyata terhadap berat kering berangkasan tetapi berangkasan kering dari tanaman yang diberikan pupuk kandang dengan cara tebar cenderung lebih berat sedangkan berangkasan kering dari tanaman yang diberikan pupuk kandang dengan cara fertigasi paling ringan.

Tabel 14. Berat Kering Berangkasan (t/ha)

\begin{tabular}{ccccc}
\hline \multirow{2}{*}{ Jenis Pupuk } & \multicolumn{3}{c}{ Cara Aplikasi } & \multirow{2}{*}{ Rerata } \\
\cline { 2 - 4 } & Tebar & Pop Up & Fertigasi & \\
\hline Ayam & $24,222 \mathrm{a}$ & $22,111 \mathrm{a}$ & $20,778 \mathrm{a}$ & $22,370 \mathrm{a}$ \\
Sapi & $21,889 \mathrm{a}$ & $22,778 \mathrm{a}$ & $22,556 \mathrm{a}$ & $22,407 \mathrm{a}$ \\
Kambing & $22,111 \mathrm{a}$ & $21,667 \mathrm{a}$ & $19,444 \mathrm{a}$ & $21,074 \mathrm{a}$ \\
\hline Rerata & $22,741 \mathrm{a}$ & $22,185 \mathrm{a}$ & $20,926 \mathrm{a}$ & $(-)$ \\
\hline Keterangan : & $\begin{array}{l}\text { Angka pada baris dan kolom yang diikuti dengan huruf yang sama } \\
\\
\end{array}$ & tidak berbeda nyata menurut uji DMRT $\alpha$ 5\%. (-) : Tidak terjadi \\
& interaksi antar faktor
\end{tabular}

\subsection{Indeks Panen}

Hasil sidik ragam (Anova) menunjukkan bahwa interaksi antara jenis dan cara aplikasi pupuk kandang berpengaruh nyata terhadap indeks panen dimana tanaman yang diberikan pupuk kandang kambing dengan cara fertigasi memiliki indeks panen paling tinggi yang berbeda nyata dengan indeks panen dari tanaman yang diberikan pupuk kandang ayam dengan cara tebar dan indeks panen dari tanaman yang diberikan pupuk kandang sapi dengan cara pop up tetapi tidak berbeda nyata dengan indeks panen tanaman yang diberikan perlakuan dengan kombinasi yang lainnya.

Jenis pupuk kandang tidak berpengaruh nyata terhadap indeks panen tetapi data Tabel 15. menunjukkan bahwa indeks panen tanaman yang diberikan pupuk kandang kambing cenderung lebih tinggi sedangkan indeks panen tanaman yang diberikan pupuk kandang ayam paling rendah. Cara aplikasi pupuk kandang tidak berpengaruh nyata terhadap indeks panen tetapi tanaman yang diberikan pupuk kandang dengan cara pop up memiliki indeks panen yang cenderung lebih tinggi sedangkan indeks panen dari tanaman yang diberikan pupuk kandang dengan cara fertigasi paling rendah.

Tabel 15. Indeks Panen (\%)

\begin{tabular}{cllll}
\hline \multirow{2}{*}{ Jenis Pupuk } & \multicolumn{3}{c}{ Cara Aplikasi } & \multirow{2}{*}{ Rerata } \\
\cline { 2 - 4 } & \multicolumn{1}{c}{ Tebar } & Pop Up & Fertigasi & \\
\hline Ayam & $56,3 \mathrm{c}$ & $63,1 \mathrm{ab}$ & $60,4 \mathrm{abc}$ & $59,9 \mathrm{a}$ \\
Sapi & $63,5 \mathrm{a}$ & $60,7 \mathrm{abc}$ & $58,4 \mathrm{bc}$ & $60,9 \mathrm{a}$ \\
Kambing & $63,1 \mathrm{ab}$ & $60,6 \mathrm{abc}$ & $63,9 \mathrm{a}$ & $62,5 \mathrm{a}$ \\
\hline Rerata & $61,0 \mathrm{a}$ & $61,5 \mathrm{a}$ & $60,9 \mathrm{a}$ & $(+)$ \\
\hline Keterangan : & Angka pada baris dan kolom yang diikuti dengan huruf yang sama \\
& tidak berbeda nyata menurut uji DMRT @ 5\%. ( + ) : Terjadi \\
& interaksi antar faktor
\end{tabular}

3.16 Pembahasan

Hasil panen tomat berupa berat buah per anak petak menunjukkan bahwa setiap jenis pupuk memiliki cara aplikasi yang berbeda-beda agar dapat 
mencapai hasil total panen yang maksimum. Pupuk kandang ayam lebih baik jika diaplikasikan dengan cara pop up, pupuk kandang sapi lebih baik jika diaplikasikan dengan cara tebar sedangkan pupuk kandang kambing lebih baik jika diaplikasikan dengan cara fertigasi.

Pemberian pupuk kandang ayam dengan cara pop up memberikan hasil tomat yang lebih tinggi dibandingkan jika diaplikasikan dengan cara tebar maupun fertigasi. Diduga bahwa hal ini terjadi akibat sifat pupuk kandang ayam yang proses dekomposisinya berlangsung cepat sehingga akan lebih baik jika penempatannya di sekitar daerah perakaran tanaman agar langsung bisa diserap, jika ditebar dan dicampur secara merata dengan tanah atau diberikan dengan cara fertigasi maka pupuk kandang ayam lebih cepat tercuci dan unsur hara tidak sempat dimanfaatkan oleh tanaman.

Berbeda dengan pupuk kandang ayam, pemberian pupuk kandang sapi dengan cara tebar memberikan hasil tomat yang lebih tinggi dibandingkan hasil yang diperoleh jika diberikan menggunakan cara pop up maupun fertigasi. Dengan cara tebar dan dicampur dengan tanah maka pupuk kandang sapi akan tersebar dan tersedia secara merata dalam tanah sehingga akar tanaman dapat secara leluasa menjangkau unsur hara yang diberikan, jika dengan cara pop up atau fertigasi maka unsur hara akan terkonsentrasi pada area sekitar tanaman dan akan mudah tercuci akibat penyiraman.

Pemberian pupuk kandang kambing dengan cara fertigasi memberikan hasil tomat yang lebih tinggi dibandingkan hasil yang diperoleh jika diberikan menggunakan cara tebar maupun pop up. Diduga hal ini terjadi karena dengan cara fertigasi maka bentuk fisik pupuk kandang kambing yang padat dan cukup keras akan hancur dan terurai dalam air selama perendaman sehingga kandungan unsur hara yang ada di dalamnya akan lebih mudah menjadi tersedia untuk diserap oleh tanaman. Sedangkan jika diaplikasikan dengan cara tebar ataupun pop up, pupuk kandang kambing belum tersedia bagi tanaman untuk jangka waktu yang pendek.

\section{Simpulan}

Dari analisis hasil dan pembahasan yang dilakukan maka dapat disimpulkan beberapa hal sebagai berikut:

a. Interaksi antara jenis dan cara aplikasi pupuk kandang hanya berpengaruh nyata terhadap diameter batang 14 HST, jumlah buah per anak petak dan indeks panen.

b. Jenis pupuk kandang nyata mempengaruhi suhu tanah setiap waktu pengamatan, berat volume tanah 14 HST, tinggi tanaman 14 HST dan 28 HST, berat per buah, jumlah buah per tanaman dan jumlah buah per anak petak, sedangkan cara aplikasi berpengaruh nyata terhadap kadar lengas tanah 28 HST, tinggi tanaman 42 HST, diameter batang 14 HST dan 28 HST.

c. Setiap jenis pupuk kandang mempunyai cara aplikasi yang berbeda untuk berfungsi dengan baik terhadap tanaman tomat, pupuk kandang ayam lebih baik jika diaplikasikan menggunakan cara pop up dengan hasil mencapai 74,543 t/ha, pupuk kandang sapi lebih baik jika diaplikasikan menggunakan cara tebar dengan hasil mencapai 74,468 t/ha sedangkan pupuk kandang kambing lebih baik jika diaplikasikan menggunakan cara fertigasi dengan hasil mencapai 71,714 t/ha.

Pustaka

Asniah, Khaerinu A dan Anwar H. 2012. Penggunaan Pupuk Kandang Terhadap Efektifitas Trichoderma viride untuk Mengendalikan Penyakit Layu Fusarium Pada Tanaman Tomat. J. Agroteknos. 2(1)28-35.

BPS TTU. 2014. Timor Tengah Utara Dalam Angka. BPS TTU. Kefamenanu.

Gomez K A dan Gomez A A. 1995. Prosedur Statistik untuk Penelitian Pertanian. Edisi ke 2. Jakarta: UI Press.

Novizan. 2004. Pemupukan Yang Efektif. Makalah Pada Kursus Singkat Pertanian. Mitratani Mandiri Perdana. Jakarta

Santoso. 1994. Komposisi Zat Gizi Buah Tomat. Penebar swadaya: Jakarta

Tugiyono. 2001. Bertanam Tomat. Penebar Swadaya Jakarta. 